\title{
Editors’ Notes
}

\section{AWARDS AT THE 2020 ECONOMIC HISTORY ASSOCIATION MEETINGS}

The Economic History Association announced the 2020 prize winners at the Annual Meeting held virtually.

Felipe González, Pontificia Universidad Católica de Chile, Mounu Prem, Universidad Del Rosario Economics, and Francisco Urzúa I, City University of London, were awarded the Arthur H. Cole Prize for the outstanding article published in this JOURNAL in the September 2019 to June 2020 issues, for "The Privatization Origins of Political Corporations: Evidence from the Pinochet Regime," published in the June 2020 issue of The Journal of Economic History. The editorial board selected the winner.

Sarah Quincy, Vanderbilt University, received the Allan Nevins Prize for the Best Dissertation in U.S. or Canadian Economic History, for her dissertation "Back to Good Times: The Real Effects of Credit in Great-Depression California," completed at the University of California, Davis. Advisors: Alan M. Taylor, Christopher M. Meissner, Katherine Eriksson, and James Cloyne. (This prize is awarded on behalf of Columbia University Press.)

Robin John Charles Adams, Queen's University Belfast, received the Alexander Gerschenkron Prize for the Best Dissertation in non-U.S. or Canadian Economic History, for his dissertation "Shadow of a Taxman: How and by whom was the Republican Government Financed in the Irish War of Independence (1919-1921)," completed at Oxford University. Advisors: Kevin Hjortshøj O’Rourke and Senia Pašeta.

Anne McCants, MIT, was awarded the annual Jonathan Hughes Prize honoring excellence in teaching economic history.

Benjamin Sidney Michael Schwantes was awarded the Alice Hanson Jones Biennial Prize for the outstanding book on North American Economic History. He was awarded for his book The Train and the Telegraph: A Revisionist History, published by Johns Hopkins University Press, 2019.

Sam Williamson, Measuring Worth, was awarded the Engerman-Goldin Prize for creating, compiling, and sharing data and information with scholars.

TAYLOR JAWORSKI, University of Colorado, Boulder, was awarded for Excellence in Refereeing for the Journal of Economic History.

Latika Chaudhary, Naval Postgraduate School, was awarded for Exceptional Service to the Journal of Economic History Editorial Board. 


\section{THE 2021 ECONOMIC HISTORY ASSOCIATION MEETINGS \\ TUCSON, ARIZONA \\ SEPTEMBER 10-12, 2021 \\ JOHN WALLIS}

The theme for EHA 2021 is "Rules, Organizations, and Governments: Institutions and Economic History." Over the last two and a half centuries, the economies of the world have dramatically transformed. Part of these transformations occurred in and resulted from technology, demography, and markets. Part of these transformations occurred in and resulted from institutions. The way societies organize themselves, in both public and private spheres, exhibits marked patterns across the range of developed and developing nations. While we know what the patterns are, as economic historians and social scientists generally, we have struggled to understand how the patterns developed or how we might induce the patterns of developed societies in developing (or undeveloped) societies. The program committee calls for papers that take a more granular approach to questions related to institutions, collective decision making, and rules that originate in organizations. Organizations ranging from families to businesses to governments (which are organizations of organizations) all adopt rules, whether they enforce them or not. How these rules and organizations interact determines the institutional structure of all societies. Proposed papers on all areas of economic history are welcome, and graduate students are encouraged to attend.

The Program Committee, co-chaired by Howard Bodenhorn (Clemson University) and Eric Hilt (Wellesley), welcomes submissions on all subjects in economic history, though some preference will be given to papers that fit the theme of the conference. Papers should be submitted individually, but authors may suggest to the Committee that three particular papers fit well together in a panel. Papers should, in all cases, be works in progress rather than accepted or published work. Submitters should let the program committee know at the time of application if the paper they are proposing has already been submitted for publication. Individuals who presented or co-authored a paper given at the 2020 meeting are not eligible for inclusion in the 2021 program. Papers and session proposals should be submitted online, with the following submission form: https:/eh.net/eha/2021-eha-meeting-proposal/. The submission system will be available from 1 November 2020 onward. Paper proposals should include a 3-5 page proposal and a 150-word abstract suitable for publication in the Journal of Economic History. Paper proposals should be submitted by 31 January 2021 to ensure consideration. Please note that at least one of the authors needs to be a member of EHA.

Graduate students are encouraged to attend the meeting. The association offers subsidies for travel, hotel, registration, and meals, including a special graduate student dinner. A poster session welcomes work from dissertations in progress. Applications for the poster session are due no later than 21 May 2021 online on the meetings website. The poster submission system will open on 1 March 2021. 
The dissertation session, convened by Martha Olney (University of California, Berkeley) and Steven Nafziger (Williams College) will honor six dissertations completed during the 2020-2021 academic year. The submission deadline is 15 May 2021. The Allan Nevins and Alexander Gerschenkron prizes will be awarded to the best dissertations on North American and non-North American topics, respectively. Dissertations must be submitted as a single PDF file. Files of less than $5 \mathrm{MB}$ in size may be sent directly to the conveners as an email attachment. To submit a file over 5 MB, please supply a download link in an email message. The Nevins prize submissions should be sent to olney@econ.berkeley.edu and the Gerschenkron prize submissions to snafzige@williams.edu. All submissions will be acknowledged by return email.

\section{EHA GRANT AND FELLOWSHIP AWARDS}

The Committee on Research in Economic History (CREH) of the Economic History Association is charged with administrating the Association's project of assisting young scholars as a way of strengthening the discipline of economic history. The CREH made three types of awards for 2020: fellowships to graduate students writing their dissertations; travel/data grants to graduate students in the early stage of research; and Cole Grants to recent PhDs.

\section{Sokoloff Dissertation Fellowships}

Brian Marein of University of Colorado, Boulder for "The Economic Development of Puerto Rico After United States Annexation." Advisors: Taylor Jaworski and Carol Shiue.

Tianyi Wang of University of Pittsburgh for "Technology, Media, and Political Change.” Advisors: Randall Walsh and Osea Giuntella, Allison Shertzer, Daniel I. Rees and Douglas Hanley.

\section{EHA Dissertation Fellowships}

Jeffrey Groesbeck of Toulouse School of Economics for "The Development of Cities from 1900 to 1950." Advisor: Mohamed Saleh.

Pawel Janas of Northwestern University for "Public Goods Under Financial Distress: Evidence from Cities in the Great Depression.” Advisors: Paola Sapienza, Carola Frydman, Scott Baker, and Joel Mokyr.

\section{Cambridge University Press Dissertation Fellowship}

Matthew Lowenstein of University of Chicago for "Finance and Capitalism in Late Imperial China, 1644-1911.” Advisor: Kenneth Pomeranz. 
Cambridge University Press Pre-Dissertation Exploratory Grants

Vasily Rusanov of New York University for "Internal Migration and the Diffusion of Schooling in the United States." Advisor: Petra Moser.

Neil Silveus of University of Pittsburgh for "Decline of American Fraternalism: Sickness Insurance and Crowd-out from Workmen's Compensation." Advisor: Allison Shertzer.

\section{EHA Pre-Dissertation Exploratory Grants}

Sharbani Bhattacharjee of Auburn University for "Technology Diffusion in India during the British Colonial Rule-Evidence from the Cotton Textile Industry." Advisor: Nicolas L. Ziebarth.

Radost Holler of Bonn Graduate School of Economics for "Cooperation and Restrictive Norms." Advisor: Thomas Dohmen.

Viktor Malein of The University of Southern Denmark for "Immigrants, Modernization of Schooling and Development: The Case of German Settlers in the Russian Empire." Advisors: Philipp Ager and Francesco Cinnirella.

Alejandro Martínez-Marquina of Stanford University for "Ingraining Traditional Gender Roles in the Classroom: Evidence from the Spanish Social Service.” Advisors: Ran Abramitzky, Muriel Niederle, and Doug Bernheim.

Laura Montenegro Helfer of University of Chicago for "Market Integration, Identity formation, and Social Mobilization: The Political Effects of the South African Mineral Revolution." Advisors: James Robinson and Chris Blattman.

Jonas Friedrich Anselm Mueller-Gastell for Stanford University for "Scarcity vs. Surplus: Labor Supply and Industrialization of Finland.” Advisor: Ran Abramitzky.

Juan Sebastian Rojas Bohorquez of UCLA for "Information Disclosures and Industrial Development." Advisors: Dora Costa, Michela Giorcelli, Martin Hackmann, Simon Board, and Nico Voigtländer.

Cesia Sanchez of UC-Berkeley for "Brother, Where Art Thou? Military Unit Composition and its Effect on Casualties, Deaths by Suicide, and Employment Among America's Veterans.” Advisors: Barry Eichengreen and Ellora Derenoncourt.

\section{Arthur H. Cole Grants in Aid}

Victor Gay of Toulouse School of Economics and Institute for Advanced Study (with Lionel Kesztenbaum of INED) for "Collateral Damage? How World War One Changed the Way Women Work."

James Harrison of United States Naval Academy for "Market Integration in the 19th Century United States."

Trevor Jackson of George Washington University for "Between Independence and Impunity: The Development of Central Banking During the French Revolution."

Matthew Lowe of University of British Columbia for "Religious Revival and Social Order." 
The Association is grateful to the members of the CREH for their work in selecting the award winners. Tracy Dennison, California Institute of Technology chaired the committee. She was assisted by Gregg Huff, University of Oxford, Carl Kitchens, Florida State University, Antoine Parent, Sciences Po Lyon, Caitlin Rosenthal, UC Berkeley, and Chris Vickers, Auburn University. 